\title{
Full mouth rehabilitation of a partially edentulous patient with crossed occlusion using implant-retained RPD with zirconia occlusal table
}

\author{
Tae-Min Kwon', Chi-Won Seo1, Kyung-A Kim², Seung-Geun Ahn', Jae-Min Seo* \\ ${ }^{1}$ Department of Prosthodontics, School of Dentistry and Institute of Oral Bio-Science, Chonbuk National University, Jeonju, \\ Republic of Korea \\ ${ }^{2}$ Department of Dentistry, School of Medicine, Eulji University, Daejeon, Republic of Korea
}

Conventional removable partial dentures (RPDs) with distal extensions are associated with some problems, including lack of stability that calls for frequent relining, and cantilever actions of claps that can produce excessive loading to abutment teeth, and the need for unesthetic retentive arm clasps. Therefore, IARPDs (Implant-assisted RPD) that use implants to support or retain RPDs has been reported to improve stability, esthetics and masticatory performance of RPDs. Also, an IARPD that has zirconia occlusal table can prevent the incongruity of occlusal plane and the extrusion of antagonistic tooth. In this case of partially edentulous patient with crossed occlusion, each edentulous area was restored with implant fixed prosthesis and implant retained partial denture to suit each situation. Through the procedure, satisfactory outcomes were achieved both in functional and esthetic aspects. (J Dent Rehabil Appl Sci 2016;32(4):314-21)

Key words: implant-retained removable partial denture; Locator ${ }^{\circledR}$ attachment; crossed occlusion

\begin{abstract}
서론
후방 연장 무치악부의 수복 방법은 크게 임플란트 유 지 고정성 보철 수복과 가철성 국소의치로 나눌 수 있다.

이 중 후방 연장 가철성 국소의치는 수직력, 수평력, 그리 고 비틀림 응력에 노출되어 기능 및 이상 기능시 불리하 다. ${ }^{1}$ 또한 클래스프에 의한 비심미성, 수직 고경의 상실, 그리고 재이장을 위한 주기적 내원의 필요성 등의 단점이 있다. ${ }^{2,3}$ 이러한 상황에서 소수의 임플란트가 의치의 유지 또는 지지에 부가적으로 사용될 경우 의치의 안정성과 유지력 그리고 저작 효율을 향상시킬 수 있다..$^{46}$ 또한 임 플란트에서 유지력을 담당함으로써 클래스프을 생략하
\end{abstract}

*Correspondence to: Jae-Min Seo

Associate Professor, Department of Prosthodontics, School of Dentistry and Institute of Oral Bio-Science, Chonbuk National University, 567, Baekje-daero, Deokjin-gu, Jeonju, 54896, Republic of Korea

Tel: +82-63-250-2696, Fax: +82-63-250-2218, E-mail: jmseo@jbnu.ac.kr

Received: August 2, 2016/Last Revision: August 25, 2016/Accepted: August 29, 2016
여 과도한 응력으로부터 지대치를 보호하고 더 심미적인 국소의치 제작이 가능하다. ${ }^{7}$

본 증례는 엇갈린 교합을 가진 상하악 부분 무치악 환 자로서, 저작의 어려움, 전치부 외상성 교합, 대합치의 정 출 등의 문제를 해결하기 위해 구치부 지지와 저작 기능 회복이 필요하였다. ${ }^{8}$ 이에 각 무치악부의 상황에 맞게 임 플란트 고정성 보철과 임플란트 유지 국소의치를 제작하 여 전악 재건 시행하였고, 가철성 국소의치의 교합면을 지르코니아로 대체함으로써 마모로 인한 대합치의 정출 을 예방하고자 하였다. 주기적인 내원 및 검사를 통해 기 능적, 심미적으로 만족할만한 결과를 얻었기에 본 증례 를 보고하고자 한다. 


\section{증례 보고}

75세 남성 환자로 좌우측 무치악 부위의 저작시 통증 을 주소로 본원 보철과에 내원하였다. 구강 위생이 불량 하고 고정성 수복물의 형태가 과풍융하며 margin의 위치 가 부적절하여 치은의 발적과 부종 상태를 확인할 수 있 었다(Fig. 1A). 또한 수복물 하방의 2차 우식이 의심되었 다. 방사선 사진상 상악 좌측 무치악 부위의 잔존 치조 골의 흡수가 진행되어 구치부에 임플란트를 식립하기 위 해서는 상악동 거상술과 골이식술이 필요한 상황이었다 (Fig. 1B).

상, 하악의 불량한 금속도재 수복물과 골유착이 실패
된 \#46 임플란트를 제거하고 하악 우측의 무치악 부위에 는 새로운 임플란트를 식립하여 고정성 보철물로 수복하 기로 계획하였다. 상악 좌측의 무치악 부위는 골폭과 높 이가 부족하였고, 환자의 개인 사정상 오랜 기간 내원이 어려운 점과 경제적인 측면을 고려하여 가철성 국소의치 로 수복하기로 결정했다. 초진시 예비인상 채득하고 안궁 이전 및 악간 관계 채득하여 반조절성 교합기에 진단 모 형을 거상하였다(Fig. $2 \mathrm{~A}, 2 \mathrm{~B}$ ). 자유로 공간, 안모 계측 및 치아 길이 측정하여 수직 고경을 분석한 결과 상실을 보 이지 않아 현재 수직 고경을 유지하기로 결정하였다. 진 단 모형상에 Wax-up 시행하고 우측방 운동시 견치 유도, 좌측방 운동시 군기능 유도 교합 부여하였다(Fig. 2C).
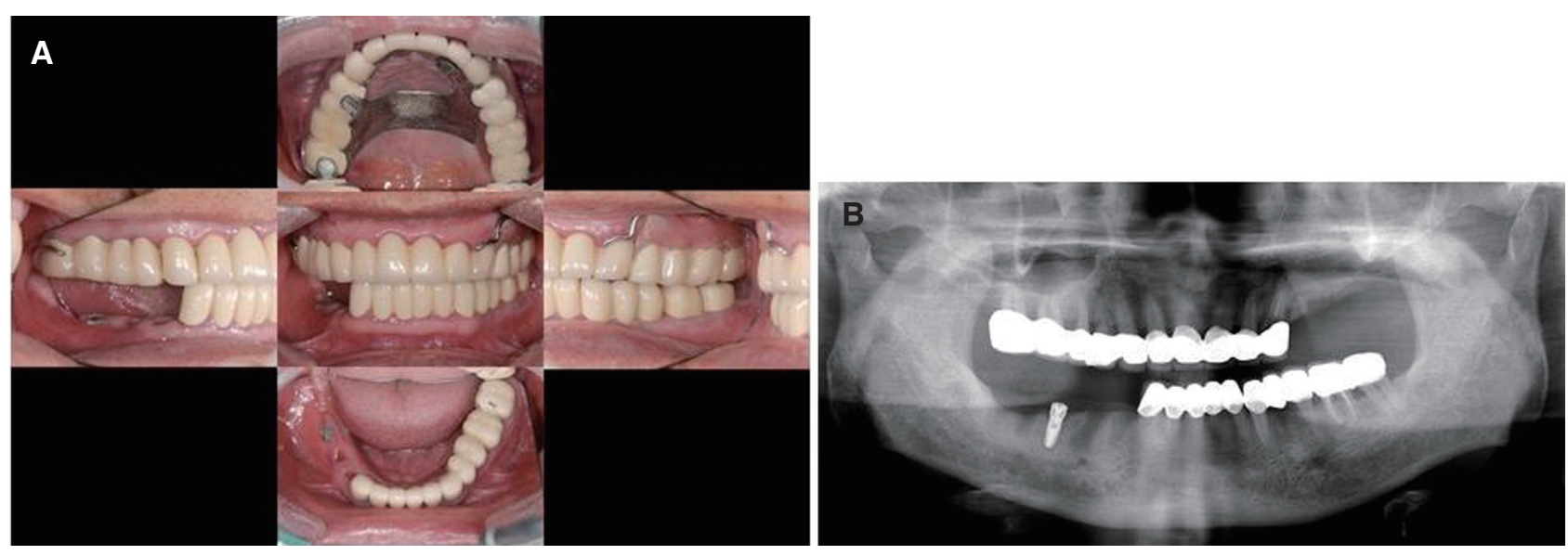

Fig. 1. First visit view. (A) Intra-oral photograph, (B) Panoramic radiograph.
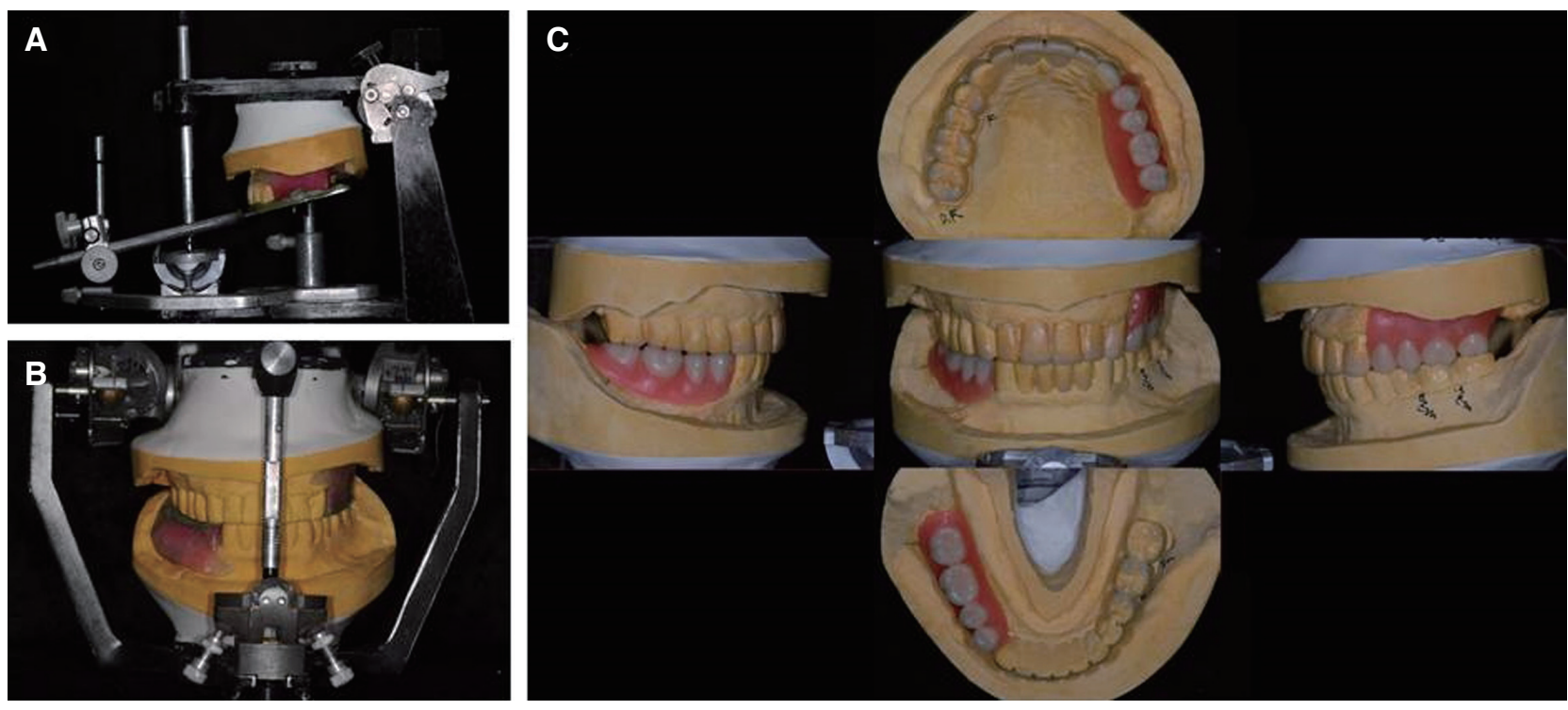

Fig. 2. Diagnosis. (A) Face-bow transfer, (B) Bite registration, (C) Diagnostic wax-up. 
상, 하악 잔존치의 모든 구 보철물을 제거하고 임시보 철물을 장착하였다. \#23, 24, 36 치아는 심한 이차우식으 로 치관이 소실되어 잔존 치근만 남은 상태였다(Fig. 3). \#23, 24 발치시 상악 무치악부의 최후방 지대치는 측절 치로서 직접적으로 의치 유지를 부담하기에 부적절하여 좌측 견치 위치에 발치 후 즉시 임플란트를 식립하고 부 착장치 (Locator ${ }^{\circledR}$, Zest anchors, Escondido, USA)를 이 용하여 상악 가철성 국소의치의 주된 유지력을 얻도록 계획하였다. 하악 우측 무치악부에 새로운 임플란트 식 립과 \#36 발치하고 즉시 임플란트 식립 후 고정성 보철 수복하기로 계획하였다

본원 치주과에서 잔존 지대치의 치주치료를 시행하였 고, 본원 보존과에서 \#43, 31, 33, 37의 이차 우식 치료 및 \#14,15,16,17의 근관치료를 시행하였다.

본원 보철과에서 고정이 불량한 \#46 임플란트를 제거
하고 즉시 \#44, 45, 46, 47 부위에 새로운 임플란트를 식 립하였다(\#44: $4.0 * 12 \mathrm{~mm}$, \#45: $4.0 * 10 \mathrm{~mm} \# 46: 5.0$ $* 8 \mathrm{~mm}$ / Superline, Dentium, Seoul, Korea, \#47: 5.0 * $7 \mathrm{~mm}$ / TS III SA, Osstem, Seoul, Korea) (Fig. 4A). 동시에, \#23, 24, 36 잔존 치근 발치 후, \#23, 36에 임플 란트를 즉시 식립하였다(\#23: $4.5 * 12 \mathrm{~mm} /$ Superline, \#36: $5.0 * 11 \mathrm{~mm}$ / TS III) (Fig. 4B, 4C). 식립 2개월 후 상, 하악 치아의 최종 삭제 시행하고 새로운 임시 보철물 제작을 위한 인상 채득하였다. 작업 모형 제작하여 안궁 이전 및 악간 관계 채득하여 교합기에 거상한 후, 개인 맞 춤형 지대주(Myplant ${ }^{\circledR}$, Raphabio Co., Busan, Korea)를 제작하고 임플란트를 포함한 모든 지대치의 고정성 임시 보철물과 상악 좌측 무치악부의 임시의치를 제작, 장착 하였다(Fig. 5).

임시 보철물 장착 2 개월 동안 환자는 합병증 없이 기
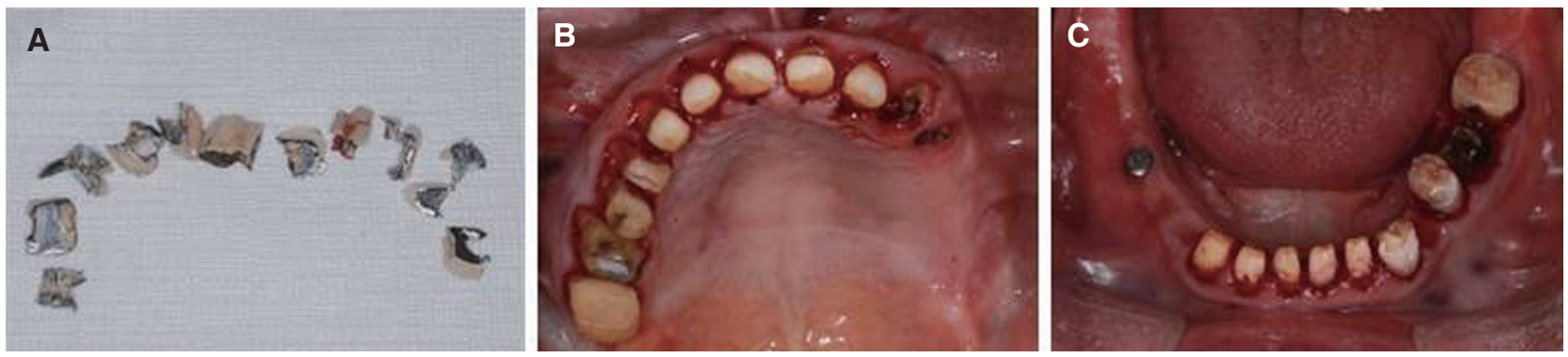

Fig. 3. Removal of old porcelain fused metal fixed prosthesis. (A) Removed prosthesis, (B) Maxillary abutments, (C) Mandibular abutment.
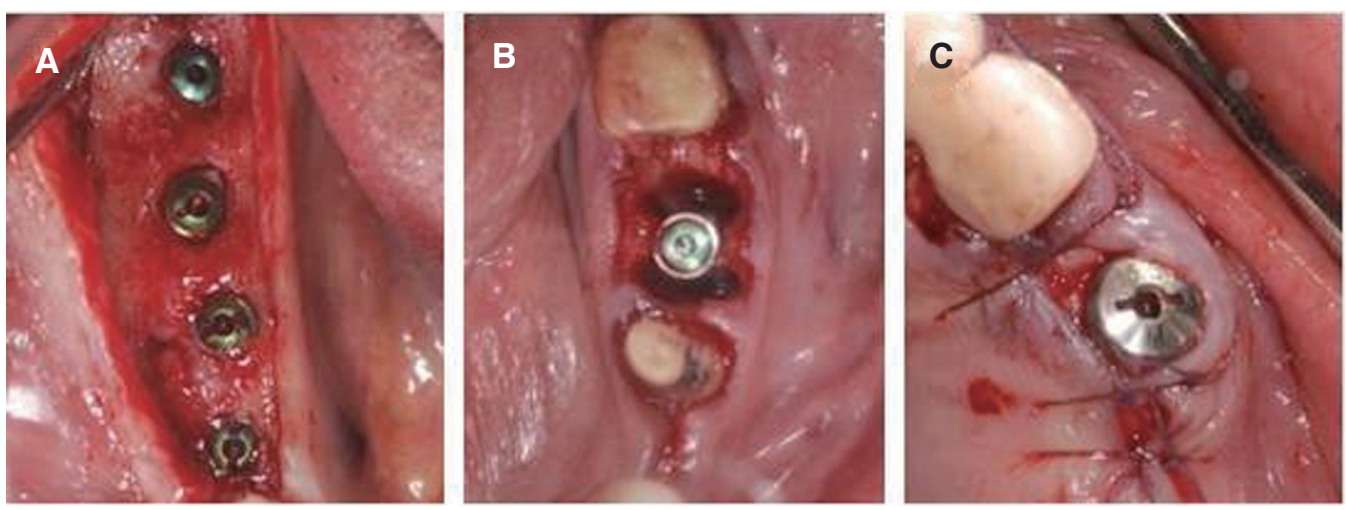

Fig. 4. Implant surgery. (A) Implantaion of right mandible, (B) Implantation of \#36, (C) Implantation of \#23. 


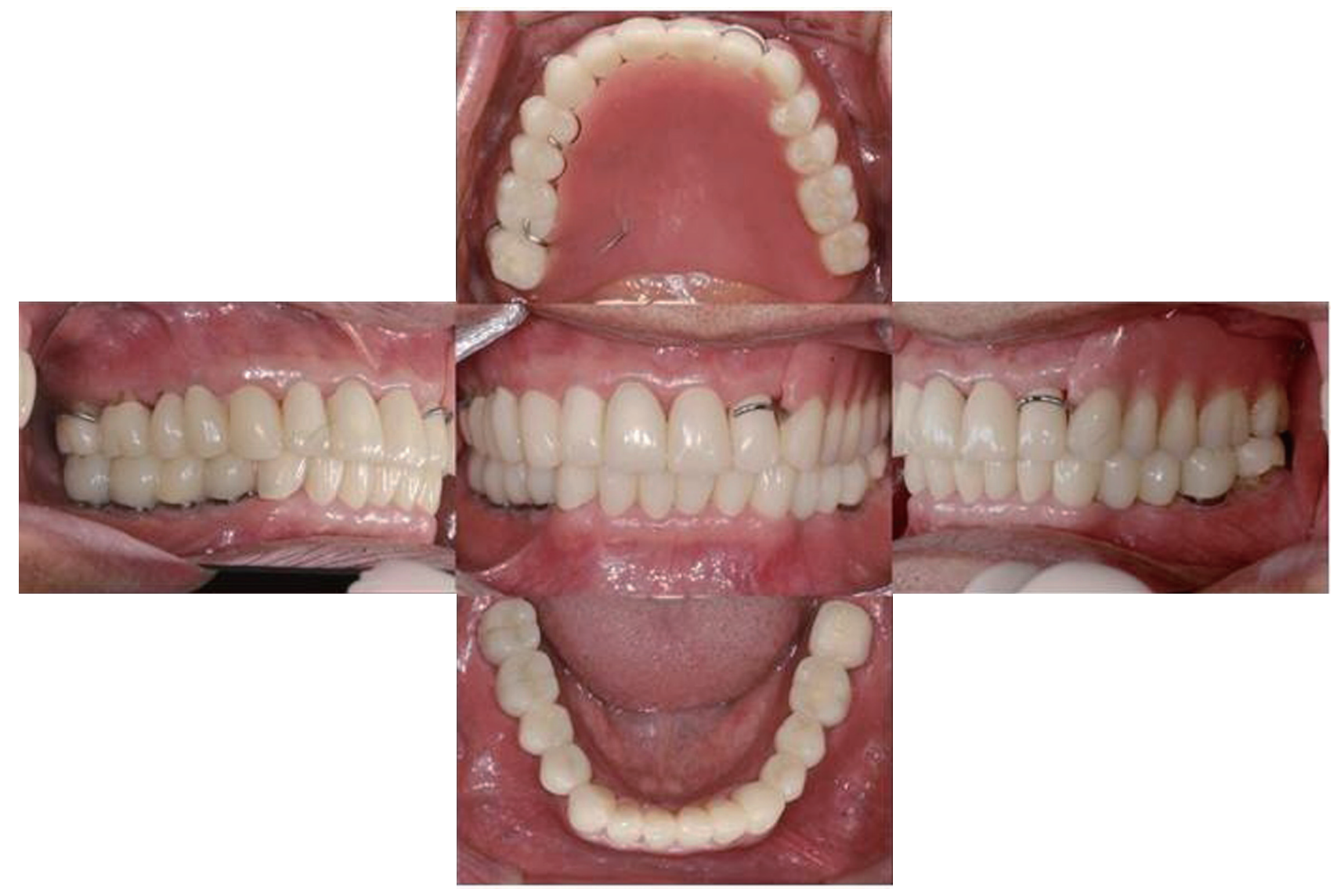

Fig. 5. Temporary prosthesis setting.
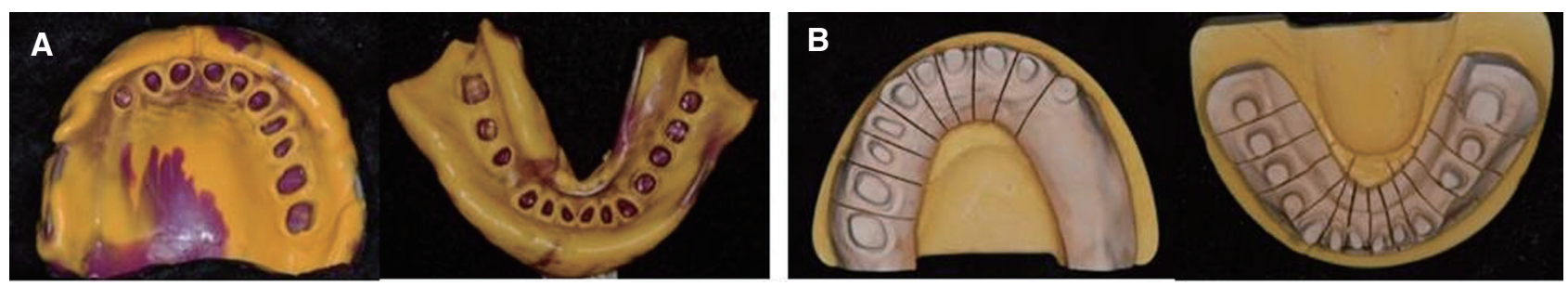

Fig. 6. Master cast fabrication. (A) Final impression, (B) Working model for fixed prosthesis.

능, 심미적으로 만족스러운 결과를 보여 부가중합형 실 리콘 인상재(Aquasil Ultra XLV, Monophase, Dentsply Caulk, Milford, USA)를 이용하여 임플란트 개인 맞춤 형 지대주를 포함한 모든 지대치의 최종 인상을 채득하 고 작업 모형을 제작하였다(Fig. 6). 임시 보철물 장착상 태에서 안궁이전을 시행하고 모형을 제작하여 개인 맞 춤형 절치유도판을 제작하였다. 악간관계를 채득하고 작업모형을 교합기에 거상 후, 최종 보철물을 제작하였 다. 상, 하악 6전치는 지르코니아 코어에 상부도재를 축
성한 zirconia based ceramics 보철물로, 구치부는 단일 구조 지르코니아 보철물로 제작하였다. 하악 우측 임플 란트를 제외하고는 모두 단관으로 제작하였다. 상, 하악 자연치 및 임플란트 지대주에 지르코니아 최종 보철물 을 합착하였다(Fig. 7). 상악의 임플란트 유지 가철성 국 소의치를 제작하기 위해 개인 트레이 제작하여 모델링 컴파운드(Peri compound, GC, Tokyo, Japan)를 이용하 여 변연 형성 시행 후 부가중합형 실리콘 인상재(Aquasil Ultra XLV, LV, Dentsply Caulk)를 이용하여 최종인상 
채득하였다(Fig. 8A, 8B). 이 후 통법에 의하여 상악 임 플란트 유지 국소의치를 제작하였다(Fig. 8C, 8D). 최후 방 지대치인 \#22 에는 wrought wire 적용하고 향후 견 치 부위 임플란트에 유지장치 (Locator ${ }^{\circledR}$ ) 부착 후 측절 치의 wrought wire는 제거하기로 계획하였다. 2주간의 settling 기간을 거친 후, Locator ${ }^{\circledR}$ 유지장치의 male part 를 상악 가철성 국소의치에 삽입하였다. 향후 인공치 마 모에 의한 교합평면의 부조화를 방지하기 위해 인공치 교합면을 지르코니아로 교체하기로 하였다. 상악 국소의 치의 pick-up 인상을 채득하고 구치부 인공치의 지르코
니아 보철물 제작 후 국소의치 상에 레진 시멘트 (RelyX Ultimate, 3M ESPE, St. Paul, USA)를 이용하여 합착하 였다. (Fig. 9). 지르코니아 교합면으로 교체한 임플란트 유지 국소의치를 최종 장착하였다(Fig. 10). 환자는 기능, 심미적으로 만족하였으며 정기적인 재내원을 통해 교합 상태 확인 및 방사선 사진 촬영하여 정기 검사 시행하였 다. 재내원 기간 중 상악 국소의치의 wrought wire에 대 한 심미적인 불만은 없었으며 오히려 이를 통해 심적 안 정을 느끼며 유지하기를 원하여 향후 필요시 제거하기로 결정하였다

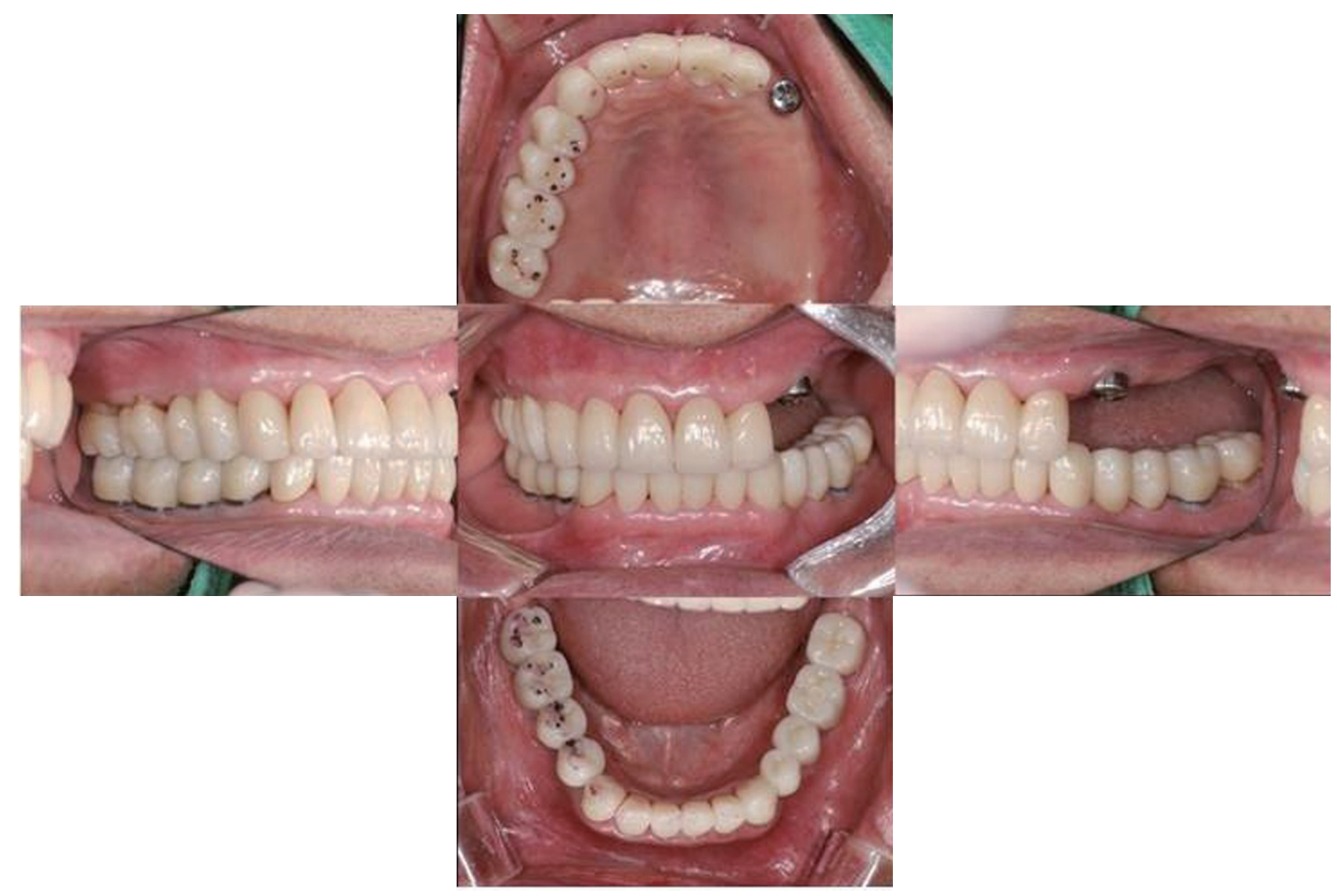

Fig. 7. Final fixed prosthesis setting.
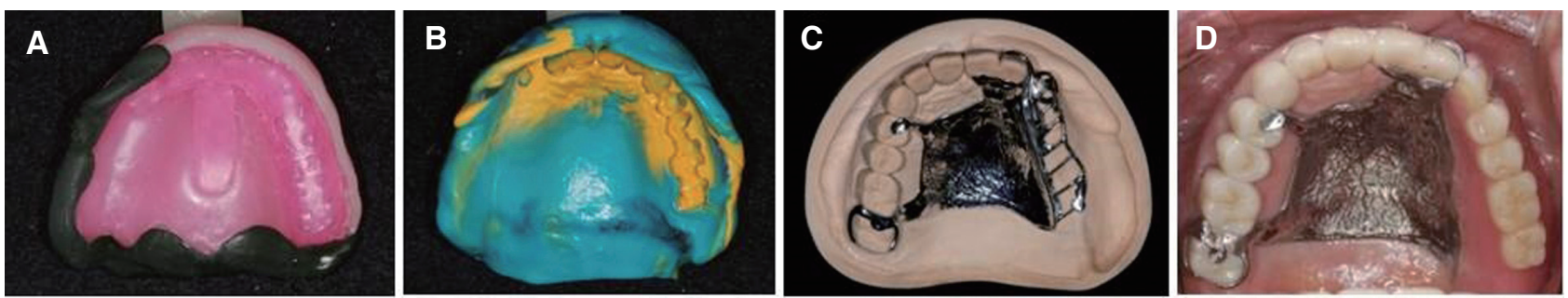

Fig. 8. (A) Border molding, (B) Final impression, (C) Framework fabrication, (D) Delivery. 

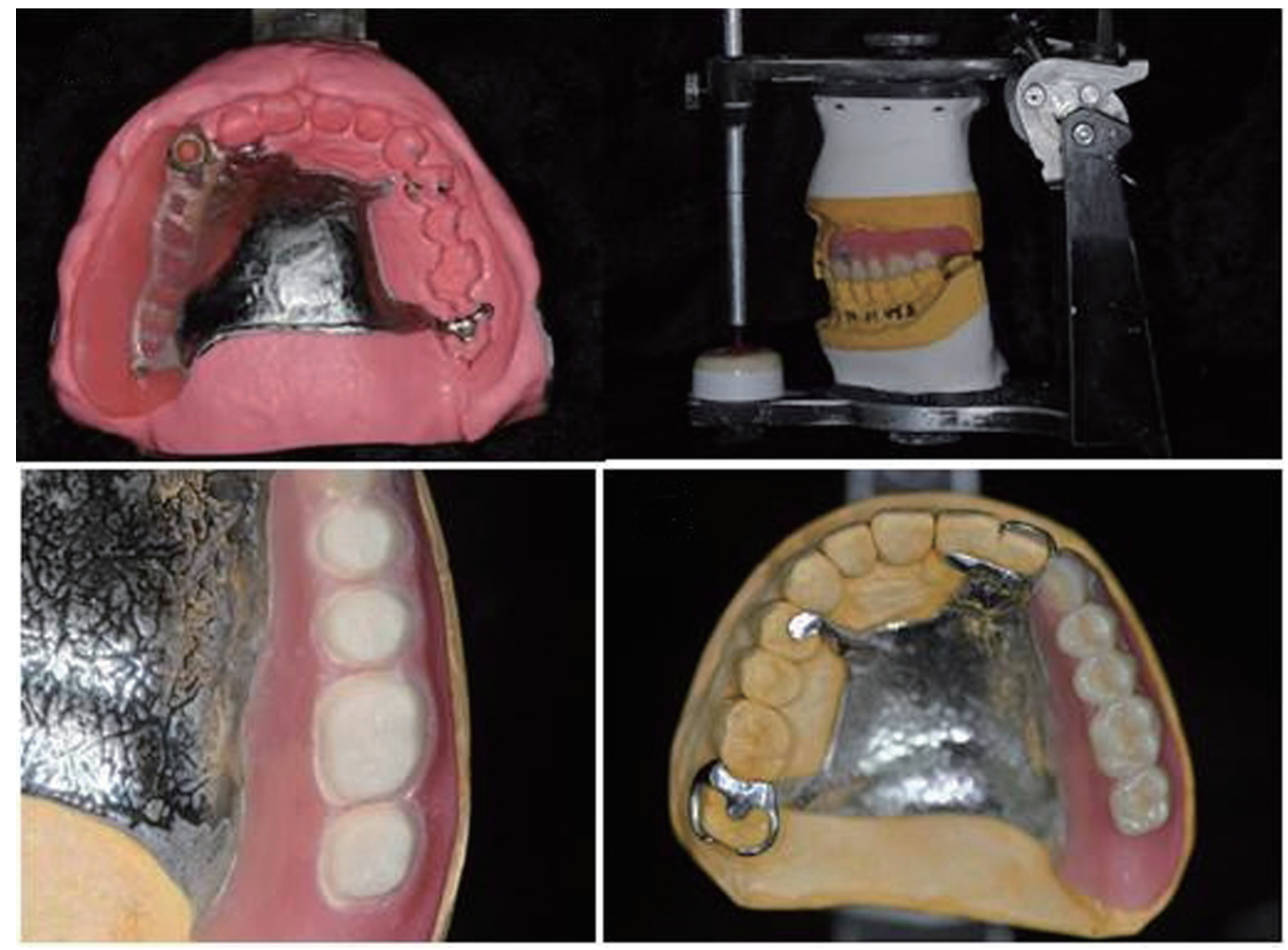

Fig. 9. Final fixed prosthesis setting.
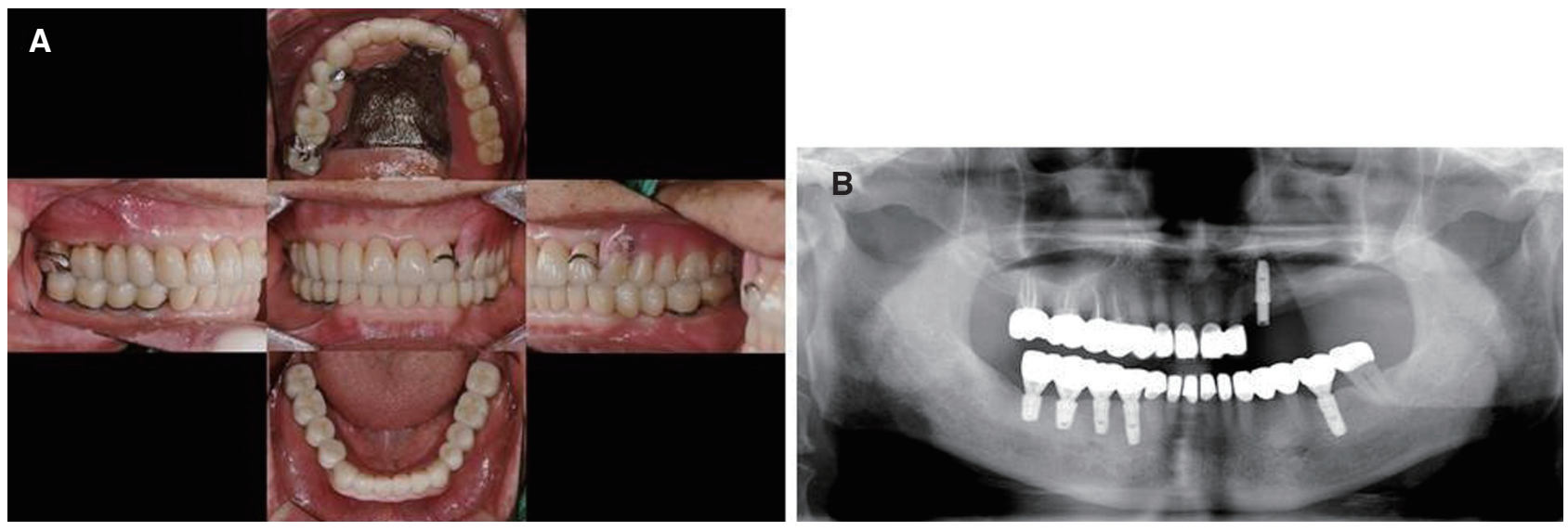

Fig. 10. Final prosthesis setting. (A) Intra-oral photograph, (B) Panoramic radiograph.

\section{고 찰}

Mahn 등은 그의 임상 연구에서 국소의치의 클래스프 는 비심미적일 뿐 아니라 지대치에 유해한 하중을 가할 수 있는데, 상악 Kennedy class II 환자에서 클래스프를
생략한 임플란트 유지 가철성 국소의치를 제작하여 장착 한 결과 안정성과 심미성을 얻을 수 있었다고 보고하였 다. 또한 Carvalho 등은 임플란트 유지 고정성 보철에 비해 임플란트 유지 가철성 국소의치는 내원기간과 기공 과정을 단축할 수 있고 최소의 임플란트 식립만을 요구 
하며, 경제적이고, 상악동 수술이 불필요한 점을 장점으 로 언급하였다. ${ }^{9}$

본 증례는 엇갈린 교합을 가진 부분 무치악 환자로 구 치부 지지와 저작기능의 회복이 필요한 상황이었다. 하 지만 상악 무치악부의 잔존 치조골 높이 및 폭이 부족하 였으며, 고정성 보철을 위한 다수의 임플란트 식립을 위 해서는 상악동 거상술 및 치조골 증대술이 필요하였으나 환자분의 경제적 사정과 오랜 기간 내원이 어려운 점을 고려했을 때 임플란트 고정성 보철 수복은 어려울 것으 로 판단하였다. 이에 가용골이 충분한 상악 무치악 부위 의 전방부에 단일 임플란트를 식립하고 유지장치를 부착 하여 이를 통해 주된 유지를 얻는 국소의치를 설계하고, 최후방 지대치(\#22)의 클래스프를 생략하여 유해한 응 력으로부터 보호할 수 있도록 제작하였다.

국소의치의 또 다른 단점으로는 강도가 약한 인공치 를 사용하여 과도한 마모가 일어날 경우, 최초에 설정한 교합 양식이 붕괴되는 점을 들 수 있다. Ghazal 등은 아 크릴릭 레진 인공치가 법랑질보다 쉽게 마모됨을 보고하 였고 이러한 인공치 마모는 저작 효율의 감소, 저작근의 피로 그리고 잘못된 악간관계를 야기할 수 있다고 하였 다. ${ }^{10,11}$ 이에 대합치가 세라믹 재료일 경우 동일한 세라믹 재료를 사용할 것을 추천하였다. ${ }^{2}$ 본 증례에서는 대합치 가 지르코니아 고정성 보철물임에 착안하여 가철성 국소 의치를 제작한 후 인공치를 삭제하여 지르코니아로 재수 복하여 인공치의 마모로 인한 부작용을 최소화할 수 있 도록 하였다.

\section{결론}

후방 연장 부분 무치악 환자에서 가용골이 충분한 전 방 무치악 부위에 임플란트를 식립하고 임플란트 유지 가철성 국소의치를 제작하는 방법은 비교적 비침습적으 로 경제적이며 빠르게 구강의 기능과 심미성을 회복시킬 수 있으며 더불어 약한 지대치를 보호할 수 있는 보철 수 복 방법의 하나로 제시될 수 있다

\section{ORCID}

Tae-Min Kwon http://orcid.org/0000-0002-6640-2403

Chi-Won Seo http://orcid.org/0000-0003-0745-8199

Kyung-A Kim http://orcid.org/0000-0002-2923-5351

Jae-Min Seo http://orcid.org/0000-0001-5095-4046

\section{References}

1. Giffin KM. Solving the distal extension removable partial denture base movement dilemma: a clinical report. J Prosthet Dent 1996;76:347-9.

2. Gonçalves TM, Campos CH, Garcia RC. Implant retention and support for distal extension partial removable dental prostheses: satisfaction outcomes. J Prosthet Dent 2014;112:334-9.

3. Mijiritsky E. Implants in conjunction with removable partial dentures: a literature review. Implant Dent 2007;16:146-54.

4. Rodrigues RC, Faria AC, Macedo AP, de Mattos Mda G, Ribeiro RF. Retention and stress distribution in distal extension removable partial dentures with and without implant association. J Prosthodont Res 2013;57:24-9.

5. Lee JH, Kim DG, Park CJ, Cho LR. A literature review on implant assisted removable partial denture. J Dent Rehabil Appl Sci 2012;28:179-90.

6. Fueki K, Kimoto K, Ogawa T, Garrett NR. Effect of implant-supported or retained dentures on masticatory performance: a systematic review. J Prosthet Dent 2007;98:470-7.

7. Mahn DH. Implant-retained removable partial denture. Dent Abstr 2012;57:247-8.

8. Kay KS, Kim YS, An JK. A clinical study on rehabilitation of vertical dimension in the patient with crossed occlusion. Oral Biol Res 2001;25:127-43.

9. de Carvalho WR, Barboza EP, Caúla AL. Implantretained removable prosthesis with ball attachments in partially edentulous maxilla. Implant Dent 2001;10;280-4.

10. Chong BJ, Thangavel AK, Rolton SB, Guazzato M, Klineberg IJ. Clinical and laboratory surface finishing procedures for zirconia on opposing human enamel wear: a laboratory study. J Mech Behav Biomed Mater 2015;50:93-103.

11. Ghazal M, Kern M. The influence of antagonistic surface roughness on the wear of human enamel and nanofilled composite resin artificial teeth. J Prosthet Dent 2009;101:342-9.

12. Ghazal M, Yang B, Ludwig K, Kern M. Two-body wear of resin and ceramic denture teeth in comparison to human enamel. Dent Mater 2008;24:502-7. 


\section{엇갈린 교합을 가진 부분 무치악 환자에서 지르코니아 교합면을 가지는 Implant-Retained RPD 이용한 전악 수복 증례}

권태민 ${ }^{1}$, 서치원 ${ }^{1}$, 김경아 ${ }^{2}$, 안승근 ${ }^{1}$, 서재민 ${ }^{1 *}$

${ }^{1}$ 전북대학교 치의학전문대학원 치과보철학교실 및 구강생체과학연구소

${ }^{2}$ 을지대학교 의과대학 치과학교실

기존의 후방 연장 국소의치는 재이장을 위한 잦은 내원의 필요성, 클래스프에 의한 지대치로의 과도한 응력, 클래스프의 노출에 의한 비심미성 등의 단점이 있다. 이에 임플란트를 이용하여 부가적인 지지나 유지를 얻는 Implant-assisted RPD (IARPD)는 국소의치의 안정성과 심미성, 그리고 저작 효율 증진에 도움을 줄 수 있다. 또한 의치의 교합면을 지르코니 아로 교체한다면 인공치 마모로 인한 대합치의 정출 및 교합평면의 부조화를 예방할 수 있을 것이다. 본 증례는 엇갈린 교합을 가진 상하악 부분 무치악 환자에서 임플란트 고정성 보철물과 임플란트 유지 국소의치를 제작하여 전악 재건 시 행한 증례로 주기적인 내원을 통해 기능적, 심미적으로 만족할만한 결과를 얻었기에 보고하고자 한다.

(구강회복응용과학지 2016;32(4):314-21)

주요어: 임플란트 유지 국소의치; 로케이터; 엇갈린 교합

*교신저자: 서재민

(54896) 전북 전주시 덕진구 백제대로 567 전북대학교 치의학전문대학원 치과보철학교실 및 구강생체과학연구소

Tel: 063-250-2696 | Fax: 063-250-2218 | E-mail: jmseo@jbnu.ac. kr

접수일: 2016년 8월 2일 | 수정일: 2016년 8월 25일 | 채택일: 2016년 8월 29일 